Данијела Врањеш*

Филолошки факултет

Универзитета у Београду
811.112.2’243:378.4

316.722:[811.112.2'243:378.147

316.64:811.112.2’243-057.875

https://doi.org/10.18485/zivjez.2021.41.1.8

Оригинални научни рад

Примљен 03/08/2021

Прихваћен 14/12/2021

\title{
СТАВОВИ СТУДЕНАТА ГЕРМАНИСТИКЕ О ПРИСУСТВУ ИНТЕРКУЛТУРНИХ ЕЛЕМЕНАТА У УНИВЕРЗИТЕТСКОЈ НАСТАВИ НЕМАЧКОГ КАО СТРАНОГ ЈЕЗИКА
}

Универзитетска настава немачког као страног језика најчешће се дефинише преко два аспекта: наставе савременог немачког језика и предмета који се баве знањима о језику. Предмет Савремени немачки језик тако чини окосницу наставе савременог немачког језика у оквиру модула Језик, књижевност, култура на Катедри за германистику на основним студијама на Филолошком факултету Универзитета у Београду. Стога је оправдано очекивати да се током студија студенти упознају и са културом не само земље чији језик уче, већ и земље из које долазе. Будући да су језик и култура нераздвојно повезани, циљ овог рада јесте да испита у којој мери су интеркултурни садржаји заступљени у настави Савременог језика. Истраживање је усмерено на процену студената о присутности културних елемената у настави, а за потребе истраживања сачињен је упитник. Добијени подаци послужиће као подстрех за освежавање курикулума на овом предмету.

Кључне речи: култура, интеркултурна компетенција, интеркултурна глотодидактика, културни елементи у настави, настава страног језика, интеркултурност у настави страних језика

\section{Значај интеркултурних садржаја у настави страног језика}

Учење страног језика неминовно подразумева и контакт са културом говорне заједнице (или говорних заједница) чији се језик учи, тим пре што „нема културе без језичког израза, нити пак има језика без културног садржаја" (Бугарски 2005: 16). Из тог разлога се и културни садржаји у наста-

* Универзитет у Београду, Филолошки факултет, Студентски трг 3, 11000 Београд; danijella95@gmail.com 
ви страног језика сматрају једнако важним као језички садржаји, јер знање о другој култури, као и способност њеног интерпретирања, анализе и поређења са сопственом културом доприносе развоју тзв. „интеркултурног говорника" (Бајрам 1997), односно појединца који је способан да са припадницима друге културе комуницира са што мање неспоразума, и то не само оних који почивају на његовим језичким вештинама, већ и оних који свој узрок имају у недовољном познавању културних образаца дате говорне заједнице. Важност интеркултурних садржаја у настави огледа се и у чињеници да је у Заједнички европски референтни оквир 2018. године, поред четири основне компетенције, између осталог уврштена и плурикултурна компетенција, која подразумева способност активног или пасивног коришћења сопственог лингвистичког репертоара из више језика или језичких варијетета истовремено, са циљем разумевања говорног или писаног текста израженог на једном или више страних језика или језичких варијетета, односно са циљем успешне комуникације са особама које се користе датим језиком/датим језицима (уп. ЗЕРО 2018 и ЗЕРО 2020: 30).

Међутим, управо из комплексности појма културе произлази и основно питање дидактичара наставе страних језика: која су то интеркултурна знања и вештине које један ученик страног језика треба да усаврши, и, сходно томе, који су то садржаји којима ће му то бити омогућено? Пре него што је на дидактичку сцену ступио комуникативни приступ, међу културним садржајима у настави предност је давана фактографском знању о другим културама, које је најчешће почивало на памћењу чињеница везаних за, примера ради, историјске, географске, политичке, уметничке, традиционалне и друге садржаје (уп. Крамш, 2013 74-75) - аспекти културе који ће касније бити обједињени под појмом „Култура са великим К”. Са друге стране, са појавом посткомуникативног и неокомуникативног приступа у глотодидактици, велика пажња почиње да се поклања и тзв. „култури са малим к”, односно начину живота и свакодневици неке говорне заједнице. Тако, док је Култура са великим К базирана на чињеничном знању о некој култури, дотле култура са малим к представља аспект културе који захтева преиспитивање сопственог схватања културе, као и интерпретацију, рефлексију, анализу и поређење сопствене са другим културама (уп. Мушура 2019: 44). Овакве културне специфичности Алтмајер (2007: 13) назива културним интерпретативним обрасцима, односно обрасцима усвојеним током социјализације, на основу којих тумачимо свет, а који су похрањени у колективном сећању одређене групе говорника. Будући да су ови обрасци 
од пресудног значаја за несметано учествовање у свакодневној комуникацији у одређеној говорној заједници, недостатак знања о њима може бити, и често јесте, плодно тле за мноштво неспоразума, због чега би управо они требало да представљају „темељ у проучавању културе у настави страних језика" (Кржељ 2014: 468).

\section{Предмет Савремени немачки језик 1-8}

Предмет Савремени немачки језик 1-8 фокусиран је превасходно на језичка знања, и заправо представља темељ образовања сваког студента немачког као страног језика, на ком почивају све друге компетенције - развијане у оквиру наука попут морфологије, синтаксе, лексикологије, лексикографије, текстуалне анализе и сл. - које студенти усаврше током четврогодишњег студија.

Према акредитацији из 2015. године, студенти су у обавези да на овом предмету слушају 8 часова вежби недељно на све четири године Основних академских студија. Часове држе лектори из Србије, Немачке и Аустрије, дакле како матерњи, тако и нематерњи говорници немачког језика. На овај начин студенти неминовно долазе у контакт не само са језичким варијететима језика који уче, већ и са културом различитих говорних заједница немачког језика.

У настави се не користи уџбеник, већ текстуални, граматички, сликовни и аудио-визуелни материјали из различитих извора, скројени специјално за потребе академских студија, прилагођени критеријумима Заједничког европског референтног оквира тако да на првој години одговарају нивоима Б1.1 и Б1.2, на другој години нивоима Б2.1 и Б2.2, на трећој години нивоу Ц1.1, а на четвртој години нивоу Ц1.2.

Сам курикулум организован је према четири основне компетенције: разумевање писаног и усменог текста, и говорна и писана продукција. О плурикултурној компетенцији (уп. ЗЕРО, 2020) у акредитацији овог предмета из 2015. године нема речи, што је разумљиво, с обзиром на то да је ова компетенција уврштена у ЗЕРО први пут 2018. године у издању за сараднике (ЗЕРО 2018). Управо у тренутку када Факултету предстоји увођење нове акредитације, сматрали смо да је смислено испитати да ли се у настави Савременог немачког језика, до сада фокусираног искључиво на језичке компетенције, ипак назиру елементи интеркултурне/ плурикултурне наставе. 


\section{Методологија истраживања}

За потребе истраживања састављен је упитник за студенте. Упитник се састоји из три дела: лични подаци, асоцијације у вези са појмом култура, и ставови студената о присуству интеркултурних садржаја у настави. У истраживању се полази од три хипотезе: 1) да студенти имају развијену свест о нераздвојности језика и културе, те самим тим и о важности имплементирања интеркултурних садржаја у наставу језика; 2) да на предмету Савремени немачки језик 1-8 културни садржаји нису заступљени у задовољавајућој мери, те да 3) садржај предмета Савремени немачки језик 1-8 студенте не припрема у довољној мери за боравак у некој од земаља немачког говорног подручја.

Упитник је попунило 113 студената Катедре за германистику, од чега 23 студента прве године, 28 студената друге године, 28 студената треће године, и 34 студента четврте године студија. У наставку ће бити представљени резултати истраживања.

\section{Асоцијације у вези са појмом култура}

Како наводи британски културолог Рајмонд Вилијамс, „култура је једна од две-три најкомпликованије речи енглеског језика" (цит. према Бугарски 2005: 13). Њена комплексност огледа се и у чињеници да се у стручној ли- тератури данас може наићи на широк дијапазон сложеница са кореном речи култура, попут интеркултурности, транскултурности, катакултурности, кро- скултурности или мултикултурности (детаљније в. Велш 2010). Због тога је било важно на самом почетку утврдити која то значења студенти најчешће приписују појму културе, јер се може поћи од претпоставке да ће одговори студената бити обојени њиховим почетним ставом о појму културе.

Највећи број студената (њих 68) као прву асоцијацију на појам културе наводи традииију и обичаје неког народа ${ }^{1}$ - премда углавном није спецификовано на какве обичаје се тачно мисли - затим следе уметност са 28 навода ${ }^{2}$, историја (23), књижевност (22), музика (22), одлике неког народа

1 У одговорима студената обичаји су наведени 42 пута, а традиција 26 пута; у складу са дефиницијом појма традиција у Речнику српскохрватскога књижевног језика (Матица српска, 1990), према којој се традиција дефинише као вероваюе, обичаји, правила понашања и сл. која се преносе с поколења на поколење (Књига шеста, стр. 253), одлучили смо да ова два појма објединимо под ставком традиција и обичаји.

2 Овде треба напоменути да су, неретко чак и у оквиру истог одговора, поред уметности навођени и филм, музика, кюижевност и позориште, те није сасвим јасно да ли под 
(21), језик (19), позориште (16), филм (14), свакодневица и начин живота (12), образовање (6), бонтон (6), гастрономија (6), сликарство (4), културне манифестације и фестивали (4), празници (4), веровања (4), архитектура (3), путована (2), а по једанпут су наведени политика, друштвене науке, писмо, музеји, порекло, плес, религија, мода, вредности, актуелности, баштина и цивилизација.

Разноврсност наведених асоцијација свакако сведочи о чињеници да испитаници под појмом култура не подразумевају само тзв. „Кутлуру са великим К”, већ и „културу са малим к”, премда „култура са великим К” задржава видну предност над „културом са малим к”.

\section{Интеркултурни садржаји у настави}

Када је у питању присуство интеркултурних садржаја у настави, пре свега смо желели да сазнамо да ли на Катедри за германистику, осим књижевности, постоји и засебан предмет који би се бавио искључиво интеркултурном тематиком. На ово питање 86 студената (76\%) је одговорило потврдно, 15 студената (око 13\%) није сигурно да ли постоји такав предмет, док 12 студената (око 10\%) сматра да овакав предмет не постоји на катедри. Они испитаници који су дали потврдан одговор, на питање о ком предмету је реч најчешће су наводили предмет Увод у германистику, који се предаје на првој години, и предмет Културна историја, који се предаје на четвртој години. Неколицина студената је такође навела и предмет Савремени немачки језик, што говори у прилог претпоставци да се одређени културни садржаји обрађују и у оквиру овог предмета, премда се валидност овог одговора мора довести у питање, с обзиром на то да је овај предмет, већ и према акредитацији, оријентисан претежно на језичке вештине, што би студентима морало бити познато.

Такође је било важно сазнати да ли студенти уопште сматрају да је предмет базиран искључиво на интеркултурном садржају неопходан у оквиру студијских програма на Филолошком факултету у Београду. На ово питање велика већина испитаника (90\%) одговорила је потврдно, док је $10 \%$ испитаника дало негативан одговор, што сведочи о томе да испитаници ипак имају развијену свест о нераздвојности језика и културе.

На питање које теме би требало да сачињавају садржај једног таквог предмета, одговори су разнолики и умногоме су у складу са одговорима да-

уметношћу студенти подразумевају искључиво сликарство, или је овај термин употребљен као хипероним за друге наведене појмове. 
тим на питање о асоцијацијама везаним за појам културе. Тако су поново на првом месту наведени обичаји и традииија (66 пута), затим историја (45 навода), уметност (28 навода), музика (23), свакодневица и начин живота (22), политика (17), географија (16), филм (15), књижевност (11), актуелности (11), познате и значајне личности (11), језик (дијалекти и језички варијетети - 11), гастрономија (9), празници (8) 3 , знаменитости (8), менталитет (6), веровања (5), спорт (5), религија (4), друштво (4), филозофија (3), образовање (3), архитектура (3), културне манифестације и фестивали (3), позориште (2), невербална комуникачија (2), наука (2), бонтон (2), а по једанпут су наведени и стереотипи, животни стандард, економија, мода, плес, сочијални програми, закони, музеји, митови, телевизија и живот младих. Неколико испитаника је такође изразило потребу да се ови садржаји доводе у везу са културом Србије, што потврђује да међу испитаницима постоји свест о важности познавања сопствене културе, али о важности интерпретације сопствене у односу на стране културе, јер се, сходно етноцентричном погледу на културу, свака страна култура неминовно посматра кроз призму сопствене културе (уп. Бугарски 2005, стр. 33). Осим тога, учесталост појединачних одговора на питање садржаја предмета који би се бавио искључиво културом још једном потврђује превласт „Културе са великим К” над „културом са малим к”.

\section{Интеркултурни садржаји у оквиру предмета Савремени немачки језик}

Када је утврђено да постоји потреба за интеркултурним садржајима у оквиру појединачних студијских програма, следећи корак јесте утврђивање потребе за оваквим садржајима у оквиру самог предмета Савремени немачки језик. На питање да ли су интеркултурни садржаји неопходни у овкиру овог предмета, 90 испитаника (80\%) је дало потврдан одговор, док 23 испитаника (20\%) не сматрају ове садржаје неопходним. Оваква статистика још једном подвлачи свест студената о нераздвојној повезаности језика и културе.

Од 90 испитаника који интеркултурне садржаје сматрају неопходним у настави Савременог немачког језика, највећи број сматра да у те садржаје треба уврстити традицију и обичаје и уметност (музика, филм, књижевност, позориште, сликарство...) (по 76 испитаника), друге по реду су културне манифестаиије са 66 гласова, затим регионалне културне спеиифичности (65), стереотипи и предрасуде (60), вербална и невербална комуникација (58), ис-

3 Празници би такође могли да се подведу под ставку традиција и обичаји. 
торија и друштвено уређење са по 56 гласова, географија (51), гастрономија (50), интерперсонална комуникащија (41), док најмањи број испитаника неопходним садржајима сматра политички живот (39), економију (28) и администрацију $(26)^{4}$.

У складу са основним циљем истраживања, испитаницима је постављено питање да ли су у досадашњој настави Савременог немачког језика били заступљени неки интеркултурни садржаји. На ово питање $91 \%$ испитаника је одговорило потврдно, а само 9\% одречно, што сведочи о чињеници да је и међу наставним особљем препознат значај ових садржаја и да они, поред чисто језичких садржаја, већ чине саставни део наставе на овом предмету. Према речима испитаника, интеркултурни садржаји су највише заступљени на првој години (59 навода), нешто мање на другој години (35 навода), а најмање на трећој и четвртој години (10 и 13 навода).

Када је реч о садржајима који су обрађивани током наставе, још једанпут су најчешће наведени традиција и обичаји (41), затим музика (27), историја (24), празници (слављење Божића и Ускрса - 22), политика (16), књижевност (13), географија (11), стереотипи (11), регионалне специфичности Немачке, Аустрије и Швајиарске (10), гастрономија (8), језик (изреке и дијалекти - 8), историјске личности (7), образовни систем (7), филм (7), друштво (4), културне манифестащије и фестивали (4), мода (3), вербална и невербална комуникаиија (3), сочијални проблеми (3), веровања (2), позориште (2), а по једанпут су наведени религија, знаменитости, актуелности и спорт. Неколико студената је такође споменуло и организовање филмских вечери као додатне активности ван наставе. За саме садржаје највећи број испитаника изјављује да су били изузетно корисни, а као разлог се начешће наводи да су кроз текстове и дискусије овог типа лакше и ефикасније савладали језик и усвојили нове речи и фразе. У овом сегменту се, дакле, још једном потцртава међусобни однос језика и културе. Други лајтмотив који се провлачи кроз одговоре испитаника јесте да су им интеркултурни садржаји у великој мери приближили заједницу чији језик уче, њихов менталитет и обичаје, те их на тај начин боље припремили за боравак у циљним земљама и пружили адекватно опште образовање о њима. На овом месту јасно долази до изражаја потреба студената за „културом са малим к”. Испитаници у уврштавању интеркултурних садржаја у наставу Савременог немачког језика виде и значајан подстрех за самостално истраживање других сличних садржаја и наводе да им они олакшавају и улепшавају учење језика јер су занимљи-

4 Одговори су били понуђени и било је могуће одабрати више одговора. 
ви. Неки од испитаника изјављују да су стечена знања могли да употребе и у пословне сврхе, али и да их радо преносе другим људима као занимљивости. Као посебно корисни садржаји наведени су историја и политика, јер пружају бољи увид у актуелно стање у циљним земљама, као и садржаји везани за образовни систем, вероватно због тога што Универзитет у Београду нуди могућност размене студената са многим градовима из земаља немачког говорног подручја.

На основу досадашњих одговора испитаника лако се долази до закључка да је у настави Савременог немачког језика интеркултурним садржајима поклоњена изузетно велика пажња. Међутим, од велике важности је и повратна информација о томе и да ли испитаници сматрају да неки инеркултурни садржаји недостају у настави. На ово питање 38 испитаника је одговорило одречно, што чини нешто више од трећине оних испитаника који су изјавили да су интеркултурни садржаји били присутни у настави Савременог немачког језика. Као садржаји који недостају у настави најчешће су наведени традищија и обичаји (11 навода), што делује збуњујуће када се узме у обзир чињеница да су ови садржаји до сада навођени као највише заступљени садржаји у настави. Ипак, чини се да је потреба за њима ипак нешто већа од њихове заступљености. Осим тога, испитаници би желели да добијају више препорука за филмове, серије и музику (10 навода), као и да организују више дискусија о филмовима (5). Неки такође сматрају да је неопходно више говорити о политици (8) и више се бавити свакодневним говором и дијалектима, уместо да се учи само стандардни немачки језик (8). Као један од недостатака наведена је и анализа модерних књижевних дела, будући да се на настави књижевности обрађују дела до Другог светског рата, али не и дела настала након тог периода. Као садржаји који недостају спорадично су навођени и историја (4), актуелности (4), уметност (4), администраџија и правни систем (4), културне манифестаиије и фестивали (4), географија (3), позориште (2), а констатовано је и да је потребно чешће доводити ове садржаје у везу са културом у Србији и културом других земаља (онда када се за то укаже згодна прилика). Ипак, чини се да испитаници као највећи недостатак не виде недостатак самих садржаја, већ пре њихову недовољну обрађеност. Велики број студената наводи да су политичке теме пречесто обрађиване, науштрб других области, као и да су садржаји о којима је било речи током наставе обрађивани недовољно исцрпно, те се предлози студената за побољшање наставе односе пре свега на већи број часова посвећених интеркултурној тематици.

Дакако, интеркултурна настава не подразумева присуство искључиво 
садржаја везаних за циљну културу, већ претпоставља и њихово довођење у везу са полазном културом, или са неким другим културама онда када је то упутно. Међутим, свега две трећине студената изјављује да су културни садржаји везани за циљну земљу на настави Савременог немачког језика довођени у везу са културом Србије. У овом контексту најчешће је навођено поређење српског и немачког образовног система, затим поређење традиције и обичаја у датим земљама, као и прослављање Божића и Ускрса у Србији и земљама немачког говорног подручја. Анализиране су такође и теме везане за различите социјалне проблеме, попут незапослености, миграција становништва или очувања животне средине. Нешто слабије присутне су и политичке теме, а поменути су и стереотипи и предрасуде о Србима и Немцима.

За стицање интеркултурних искустава од велике важности је и посета циљној земљи/циљним земљама - барем је тог мишљења око 95\% испитаника. Упркос томе, велика већина испитаника (72\%) изјављује да до сада није имала прилику да посети циљну земљу на дужи период, при чему би користили језик у пословне, стручне или комуникационе сврхе; свега око $13 \%$ њих ју је са овим циљем посетило једанпут, а око $14 \%$ испитаника је са овом могућношћу у циљној земљи боравило неколико пута. Од малог броја испитаника који су посетили циљну земљу и имали прилику да током боравка усаврше своје језичке вештине (31 испитаник), укупно 9 њих је то учинило у оквиру програма мобилности, а 17 испитаника је у циљну земљу путовало самостално. Овај податак може бити подстрех за даљи рад на промоцији програма мобилности међу студентима. У циљној земљи је туристички боравило скоро 80\% испитаника, од чега $44 \%$ једанпут, а $35 \%$ неколико пута, док око $20 \%$ испитаника није имало прилику да посети циљну земљу ни на овај начин.

Честа појава при боравку у страној земљи је и тзв. „културни шок”, односно осећај физичке и/или емоционалне непријатности при сусрету са страном средином (уп. Дурбаба 2016: 144). Већина испитаника (79\%) који су имали прилику да бораве у циљној земљи, међутим, наводе да нису доживели културни шок током боравка. Остатак испитаника као најчешћи културни шок наводи разлику у језичком варијетету, јер се на студијама учи стандардни немачки, тзв. Hochdeutsch, док се у различитим регионима говоре различити дијалекти. Други по учесталости јесте другачији менталитет људи, који се описује као извесна дистанцираност према странцима, чак и нељубазност; са друге стране, једна испитаница људе у Бечу описује као 
„пуне разумевања, увек спремне да помогну, па ипак се може осетити нека доза хладноће и дистанцираности која у Србији није приметна”. Неколико пута је наведена и затеченост испитаника чињеницом да се продавнице затварају у 18 часова или да не раде недељом. Као „позитиван” културни шок неколико испитаника наводи организованост превоза (,превоз стиже на време”), као и однос становника према животној средини (брига о чистоћи, организација одлагања отпада). Један испитаник је такође изразио своје изненађење бројем жена које носе хиџаб у Нирнбергу, јер је ова појава у Србији изузетно ретка.

На концу, желели смо да сазнамо да ли испитаници сматрају да их настава Савременог немачког језика, и у коликој мери, припрема за боравак у циљној земљи. Тако око 40\% испитаника изјављује да се осећају спремним за боравак у циљној земљи у погледу и језика и културе, око трећине њих сматра да их настава овог предмета за то припрема само у погледу језика, док $22 \%$ студената изјављује да се не осећају спремним за боравак у циљној земљи. Четири испитаника тврде да адекватна знања и вештине не добијају (само) у оквиру предмета Савремени немачки језик 1-8, али да постоје други предмети који их у довољној мери припремају за сличне ситуације (овде се најчешће наводи предмет Увод у германистику, који се предаје на првој години студија).

Настави Савременог немачког језика 1-8 студенти највише замерају што се политичке теме обрађују сувише исцрпно и науштрб неки других интеркултурних садржаја, као и то што се ови садржаји не обрађују довољно детаљно. Велики број испитаника изразио је, такође, и жељу да се у настави више обрађује свакодневни говор људи (нем. Umgangssprache) и дијалекти, као и ситуације из свакодневице попут живота њихвих вршњака, коришћења јавног превоза, туризма, куповних навика, или разлика у менталитету између севера и југа Немачке, као и Аустрије и Швајцарске. Иако је установљено да су најчешће заступљени садржаји везани за традицију и обичаје у земљама немачког говорног подручја, међу испитаницима је видна потреба за још сличних садржаја, а неколико њих наводи и да би желели да чују нешто више о празницима осим Божића и Ускрса. Немали број испитаника исказује и потребу за садржајима из области уметности (музике, филма, стрипа).

На питање на који начин мисле да је најпотребније побољшати наставу Савременог немачког језика 1-8, од понуђених одговора највећи број испитаника (71\%) бира гледање филмова и дискусију о њима, затим по 66\% 
испитаника исказује жељу за организовањем интернационалних пројеката са припадницима датих култура, организовањем посета одговарајућим институцијама (нпр. културном институту, ресторану националне кухиње и сл), као и за упознавањем са студентским сервисима датих земаља. Нешто више од половине испитаника одабрало је опцију увођења додатних текстова са одговарајућом тематиком, а нешто мање од половине њих се изјаснило у корист више музичких садржаја у настави и организовања истраживачког рада студената (нпр. у виду групних пројеката, презентација или семинарских радова). Један/на испитаник/ца је навео/ла и предлог организовања квизова са одговарајућом тематиком, а поред тога је једанпут наведена и могућност организовања онлајн конференција са студентима и студенткињама германистике из других земаља.

\section{Закључна разматрања и импликације за наставу}

Анализа ставова студената о присутности интеркултурних елемената у настави Савременог немачког језика показала је, пре свега, да студенти имају развијену свест о неопходности имплементирања ових садржаја у наставу, што потврђује прву хипотезу истраживања. Поред тога, јасно је да су знања и вештине стечене у области интеркултуре предуслов за лагодан боравак у некој од земаља немачког говорног подручја, чиме је трећа хипотеза истраживања оповргнута. Добијени резултати само делимично потврђују другу хипотезу: на основу резултата може се закључити да је настава Савременог немачког језика богата интеркултурним садржајима; међутим, осетна је потреба за њиховом систематизацијом и продубљивањем, те актуализацијом у виду увођења савременијих садржаја попут дискусија о актуелним догађајима, или пак обогаћивањем програма садржајима из области уметности (попут филмова, серија, музике, сликарства и др). Приметна је, такође, и доминантност садржаја из области „Културе са великим К”, док се чини да су садржаји везани за навике, начин живота и свакодневицу немачке говорне заједнице ипак скрајнути. Последица овога јесте и чињеница да се студенти, превасходно у погледу културних садржаја, након студија не осећају припремљеним за боравак у земљама немачког говорног подручја, што је свакако резултат који осветљава нове идеје за увођење извесних измена у курикулуму овог предмета. 


\section{ЛИТЕРАТУРА}

Алтмајер 2007: C. Altmayer, Von der Landeskunde zur Kulturwissenschaft Innovation oder Modetrend? Germanistische Mitteilungen Zeitschrift des Belgischen Germanisten- und Deutschlehrerverbands 65, 7-21.

Бајрам 1997: M. Byram, Teaching and Assessing Intercultural Communicative Competence. Clevedon: Multilingual Matters.

Бугарски 2005: Р. Бугарски, Језик и култура. Београд: XX век.

Велш 2010: W. Welsch, Was ist eigentlich Transkulturalität? In: L. Darowska \& C. Machold (Hrsg.), Hochschule als transkultureller Raum? Beiträge zu Kultur, Bildung und Differenz. Bielefeld [online], [http://www.alicedittmar. de/wp-content/uploads/2017/03/Wolfgang-Welsch-Was-ist-eigentlichTranskulturalit\%C3\%A4t-2009.pdf]

Дурбаба 2016: О. Дурбаба, Култура и настава страних језика. Београд: Филолошки факултет Универзитета у Београду.

Крамш 2013: C. Kramsch, Culture in Foreign Language Teaching. Iranian Journal of Language Teaching Research, 13(1), 57-78.

Кржељ 2014: K. Krželj, Interesovanja studenata za sadržaje strane kulture. Etnoantropološki problemi, 9(2), 465-481.

Мушура 2019: G. Mušura, Sticanje interkulturne komunikativne kompetencije u nastavi italijanskog kao stranog jezika u osnovnoj školi. Doktorska disertacija. Beograd: Filološki fakultet Univerziteta u Beogradu.

3EPO 2018: Council of Europe, Common European Framework of Reference for Languages: Learning, teaching, assessment. Companion volume. Cambridge: Cambridge University Press.

3EPO 2020: Council of Europe, Common European Framework of Reference for Languages: Learning, teaching, assessment. Companion volume. Cambridge: Cambridge University Press. 


\title{
Danijela Vranješ
}

\section{ATTITUDE OF GERMAN LANGUAGE STUDENTS TOWARDS THE PRESENCE OF INTERCULTURAL ELEMENTS IN UNIVERSITY GFL TEACHING}

\begin{abstract}
Summary
The subject Contemporary German language 1-8 constitutes the foundation of the Bachelor study program within the module Language, literature, culture at the Department for German studies at the Faculty of Philology, University of Belgrade. Therefore it is reasonable to expect that the students would come into contact with the culture not only of the countries whose language they are learning, but of their own culture as well during their studies. Since language and culture are inseparable, the aim of this research is to investigate to which extent the intercultural contents are present within the course Contemporary German language. The research is aimed at the students' estimation regarding the presence of cultural elements in the lessons. For the purpose of the study a questionnaire has been created. The acquired data will serve as an incentive for a refreshment of the curriculum of this course.
\end{abstract}

Keywords: culture, intercultural competence, intercultural language teaching, cultural elements in teaching, foreign language teaching, interculturality in foreign language teaching. 


\section{Danijela Vranješ}

\section{EINSTELLUNG DER GERMANISTIKSTUDIERENDEN GEGENÜBER DER ANWESENHEIT DER INTERKULTURELLEN ELEMENTE IM UNIVERSITÄREN DAF-UNTERRICHT}

\section{Zusammenfassung}

Der unviersitäre DaF-Unterricht besteht meistens aus zwei Teilen: dem Fach, das sich mit der Gegenwartssprache beschäftigt, und den Fächern, in denen das Wissen über die Sprache vermittelt wird. Das Fach Gegenwartssprache Deutsch ist somit als Grundpfeiler des DaF-Unterrichts am Lehrstul für Germanistik der Philologischen Fakultät der Universität Belgrad zu verstehen. Aus diesem Grund sind auch die Erwartungen berechtigt, dass sich die Studierenden während des Studiums (neben der Sprache an sich) ebenfalls mit der Kultur des Ziellandes, sowie mit der Kultur ihres Herkunftslandes auseinandersetzen und vertraut machen. Da Sprache und Kultur zwei Teile eines Ganzen ausmachen, wird es Ziel dieser Arbeit sein, den Anteil an interkulturellen Inhalten im Fach Gegenwartssprache Deutsch zu erforschen. Die Forschung beruht auf der Einschätzung der Studierenden über die Anwesenheit der (inter)kulturellen Elemente im Unterricht. Zum Zweck der Forschung wurde eine Umfrage erstellt, und die erhobenen Daten sollen als Anreiz zur Erfrischung des Kurrikulums in diesem Fach dienen.

Schlüsselwörter: Kultur, interkulturelle Kompetenz, interkulturelle Fremdsprachendidaktik, kulturelle Elemente im Unterricht, DaF-Unterricht, Interkulturalität im DaF-Unterricht. 